\title{
Morphological evaluation of common bean diversity on the Island of Madeira
}

\author{
Gregório Freitas · José F. T. Ganança • \\ Humberto Nóbrega • Élvio Nunes • Graça Costa • \\ Jan J. Slaski • Miguel Â. A. Pinheiro de Carvalho
}

Received: 12 May 2010/Accepted: 4 October 2010/Published online: 22 October 2010

(C) Springer Science+Business Media B.V. 2010

\begin{abstract}
The variability of fifty populations of common bean (Phaseolus vulgaris L.), representing a wide range of ecological conditions on the Island of Madeira, was evaluated based on morphological and reproductive traits. Individual data of 58 traits related to earliness, plant and tassel structure and the shape of the ear and grain were analysed using multivariate analysis. The populations belonging to two major common varieties were clustered into fifteen groups by their degree of dissimilarity, based on discriminant analysis. The dissimilarity of these groups was confirmed by one way ANOVA. The racial rank of these groups was proposed and a brief description of the common bean landraces was presented. This work represents the first morphological characterization and analysis of diversity of bean germplasm from the Archipelago of Madeira, where the traditional agricultural practices are still keeping this Portuguese region free from improved bean varieties. The description of the Madeiran bean landraces allows the preservation of
\end{abstract}

G. Freitas · J. F. T. Ganança (凹) · H. Nóbrega ·

É. Nunes · G. Costa - J. J. Slaski ·

M. Â. A. P. de Carvalho

ISOPlexis Germplasm Bank, Centre of Studies

for Macaronesia, University of Madeira,

9000-390 Funchal, Portugal

e-mail: jofitei@gmail.com

\section{J. J. Slaski}

Bioresource Technologies,

Alberta Innovates-Technology Futures,

Vegreville, AB, Canada the existing bean biodiversity and could be used for their registration as conservation landraces, or for conservation and breeding purposes worldwide.

Keywords Germplasm breeding - Madeira Island . Multivariate analysis - Phaseolus vulgaris .

Variability

\section{Introduction}

Since the beginning of their cultivation history, Phaseolus species assumed a great importance due to its role in agriculture and nutrition, providing protein, fiber, minerals and vitamins to the human diet (Broughton et al. 2003; Ying et al. 2006). Their seeds contain also a large number of bioactive compounds (Ranilla et al. 2007), which makes them an inexpensive and abundant functional food, having known benefits to human health (Cardador-Martínez et al. 2002; Broughton et al. 2003). FAO (2009) statistics shows that the world production of beans was of $18.3 \times 10^{6} \mathrm{Mt}$ in 2007 , occupying an area of $27.5 \times 10^{6}$ ha. In Portugal, the crop occupies an area of 7,945 ha, from which 1350 ha are localized in Madeira, where it annually reaches a production of 4,230 $\mathrm{t}$ (Vieira and Oliveira 2007). However, the role played by Portugal in the crop globalization and germplasm transfer (Mendes Ferrão 1992), as well as 
the traditional bean consumption, determines the existence of the present high crop biodiversity.

Phaseolus belongs to the subclass Rosidae, order Fabales, family Fabaceae, subfamily Papilionoidea (Strasburger et al. 1994) and encompasses more than 400 species (Freytag and Debouck 2002). The common bean ( $P$. vulgaris) occupies more than $85 \%$ of the total crop cultivated area in the world. Common bean genetic resources evolved from two main genetic sources of wild beans, the Mesoamerican and the Andean gene pools, and one or two smaller gene pools in the northern Andes (Koenig and Gepts 1989). The poor establishment of relationships between different domesticated species, their gene pools and the crops wild relatives (cwr) makes difficult the bean germplasm evaluation and its rational use for different purposes. Beans are an extremely diverse crop in terms of cultivation methods, uses and range of environments to which they have been adapted (Broughton et al. 2003). This diversity of conditions and genetic origin (gene pool) can manifest itself in several morphological and biochemical traits (Singh et al. 1991c), and evolve in a multitude of cultivated forms, which causes much disagreement about the crop taxonomy (Freytag and Debouck 2002) and the recognition of infraspecific units. A wide range of variation in some morphological and agronomic traits have been observed in bean cultivars (Voysest and Dessert 1991), which implies the importance of germplasm evaluation for the selection of plants with traits suitable for local conditions (CIAT 1983; Araya 2003).

In Europe, the diversity of common bean germplasm is the result of adaptation to different agroecological conditions and multiple inputs of material from both the Andean and Mesoamerican crop domestication centres (Araya 2003). However, Graham and Ranalli (1997) advocated the theory that most European cultivars are of Andean origin, and were probably introduced to Europe through the Iberian Peninsula, after the discovery of America. Portugal and Spain, especially in their northern regions, are considered a secondary centre of genetic diversity for common bean, particularly the large white seeds cultivars of common bean (Santalla et al. 2004).

The Portuguese archipelago of Madeira, located on the Atlantic Ocean, $630 \mathrm{~km}$ away from the west coast of North Africa, between the latitude of $33^{\circ} 10$ and $32^{\circ} 20 \mathrm{~N}$ and between the longitude of $16^{\circ} 10$ and $17^{\circ}$ $20 \mathrm{~W}$, where the agriculture is practiced by farmers on small plots (poios) and terraces carved into steep slopes of remote and isolated valleys, ranging from sea level to about 1,000 m.a.s.l., still keeps a large bean diversity. This crop still has an extreme importance, because it is one of the most widely used legume in local gastronomy, and it is also associated with several cultural and culinary traditions, usually based on the use of local seed production. Little is known about the introduction of beans, but there are strong indications that the crop was brought to Madeira in the seventeenth century by settlers from Brazil and South America or from mainland Portugal (Silva and Meneses 1984). The role of the Madeiran archipelago in the acclimation and agricultural experimentation of new crops, before their introduction in other regions of the world is well documented (Mendes Ferrão 1992).

The volcanic origin of the archipelago, the specific edaphic and ecological characteristics, as well as agricultural practices, have promoted the adaptation of introduced germplasm, as exemplified by the evolution of local landraces of wheat and corn (Pinheiro de Carvalho et al. 2003, 2004; Ganança et al. 2007; Pinheiro de Carvalho et al. 2008; dos Santos et al. 2009). The successful adaptation of bean crops to local conditions could explain why they are still in use by local farmers and their preferences for old regional cultivars, which are differentiated by a specific number of morphological, agronomic and nutritional traits. However, recent trends such as the decrease of rural population and the abandonment of traditional agricultural practices will lead to an irreversible genetic erosion of these cultivars in the foreseeable future.

A representative sampling of local bean resources, collected in traditional agro-systems and preserved in the ISOPlexis Germplasm Bank, at the University of Madeira, was assessed for their morpho-agronomic traits, using IPGRI (2001) descriptors. The analysis of the variability of the Madeiran bean cultivars, focusing on their morphological characterization, is of great importance for the evaluation of plant diversity and identification of local breeds. This study aims to provide an initial morphological and agronomic characterization of the Madeiran bean diversity preserved in the ISOPlexis germplasm bank, 
and to establish a reference collection with an identification system for the local landraces.

\section{Materials and methods}

Plant material

Fifty accessions of common bean germplasm were chosen from the collection of the ISOPlexis germplasm bank, representing the diversity of forms cultivated on the Island of Madeira (Table 1). These accessions were collected during several field missions, from farmer's field plots and traditional agro-systems. According to Santalla et al. (2001), 12 of these accessions belong to the Cranberry market class, 6 to Ojo de Cabra, 4 to Hen Eye, 3 each to Azufrado, Large Cranberry, Large Red
Mottled, Large Great Northern and Red Pinto, and 1 each to Black Canellini, Bayo Gordo, Small Red, Marrow, Garbancillo and Rosada. Identification of the market class of seven accessions was impossible to perform. The selection of bean accessions for the evaluation took into consideration their origin, and the wide range of ecological conditions present on Madeira, as well as previous knowledge on their morphological and reproductive traits. For each accession evaluation, a minimum sample of 40 seeds representing variability within the accession was chosen.

Field trials design

Selected accessions were studied during two vegetative cycles (2005 and 2006) on the experimental fields of the University of Madeira, Funchal, Portugal.

Table 1 Number of accessions, their local name, geographic distribution and market class of the Madeira common bean (Phaseolus vulgaris)

\begin{tabular}{llll}
\hline ISOP* & Local name & Geographical origin & Market class \\
\hline 459 & Canadiano & Ilha & Ojo de Cabra \\
460 & Vergalheiro & Santana & Cranberry \\
463 & Corno de Carneiro & Santana & Azufrado \\
478 & Filipe & Arco S. Jorge & Hen Eye \\
480 & Preto & Arco S. Jorge & Black Canellini \\
489 & Rasteiro & Arco S. Jorge & Large Cranberry \\
492 & Fava & S. Jorge & Cranberry \\
497 & Touquinho & S. Jorge & Hen Eye \\
505 & Corno de Carneiro & S. Jorge & Large Red Mottled \\
508 & Milheiro & Ilha & Cranberry \\
514 & Algarve & Ilha & Large Great Northern \\
519 & Touquinho & Santana & Cranberry \\
521 & Faial & Santana & Cranberry \\
528 & Faial & Santana & Ojo de Cabra \\
534 & Vaginha & Santana & Large Great Northern \\
541 & Manteiga & Faial & Bayo Gordo \\
668 & Preto & S. Vicente & UD \\
670 & Branco Rasteiro & S. Vicente & Large Great Northern \\
679 & Vassoura Rasteiro & Santa & UD \\
712 & Vaginha & S. Vicente & Ojo de Cabra \\
713 & Vaginha Grossa & S. Vicente & UD \\
719 & Feijão & S. Vicente & Small Red \\
722 & Açores & S. Vicente & Ojo de Cabra \\
724 & Vermelho & S. Vicente & Large Red Mottled \\
726 & Vassoura Rasteiro & S. Vicente & UD \\
730 & Boneco & Ribeira Brava & Hen Eye \\
\hline & & & \\
& & & \\
5 & & &
\end{tabular}


Table 1 continued

\begin{tabular}{|c|c|c|c|}
\hline ISOP* & Local name & Geographical origin & Market class \\
\hline 731 & Rasteiro (Vassoura) & Ribeira Brava & UD \\
\hline 732 & Vaginha & S. Vicente & Large Red Mottled \\
\hline 743 & Feijão & S. Vicente & Red Pinto \\
\hline 744 & Feijão & S. Vicente & Large Cranberry \\
\hline 748 & Rajado & S. Vicente & Ojo de Cabra \\
\hline 749 & Vaginha & S. Vicente & Azufrado \\
\hline 755 & Valinho & Santa & Hen Eye \\
\hline 757 & Feijão & Santa & Cranberry \\
\hline 760 & Vaginha & Ribeira Janela & UD \\
\hline 761 & Alfarroba & Ribeira Janela & Ojo de Cabra \\
\hline 764 & Rasteiro & Ribeira Janela & Red Pinto \\
\hline 770 & Vermelho & Santa & Cranberry \\
\hline 773 & Gordo & Santa & Cranberry \\
\hline 777 & Catarino & Ribeira Brava & Large Cranberry \\
\hline 778 & Vagem Vermelha & Ribeira Brava & Cranberry \\
\hline 798 & Riscado de Vara & Ponta Pargo & Cranberry \\
\hline 800 & Vara & Ponta Pargo & Cranberry \\
\hline 806 & Corno de Carneiro & Boaventura & Cranberry \\
\hline 809 & Vagem Vermelha & Pta Delgada & UD \\
\hline 822 & Feijão de Pé & S. Vicente & Marrow \\
\hline 824 & Rajado & Pta Delgada & Garbancillo \\
\hline 828 & Amarelo & Boaventura & Azufrado \\
\hline 829 & Feijão de Pé & Boaventura & Red Pinto \\
\hline 849 & Corno de Carneiro & S. Vicente & Rosada \\
\hline
\end{tabular}

$U D$ Unidentified class

* Code given to each accession in the ISOPlexis Germplasm Bank

Plants were sown, at the same time, in March and harvested during August. The plots were cultivated according to traditional methods used by local farmers, with high amounts of organic manure applied before planting $\left(5 \mathrm{~kg} \mathrm{~m}^{-2}\right)$, and mineral fertilizers applied during the experiment $\left(1 \mathrm{~kg} \mathrm{~m}^{-2}\right)$. All plots were irrigated once a week during the vegetative period with an average of $401 \mathrm{~m}^{-2}$. The "hill-plot" (Rodiño 2001a) experimental design was used, which allows characterizing a large number of plants in a small space. The experiments were performed in a completely randomized design, in which each experimental unit consisted of $2.5 \mathrm{~m}^{2}$ with 10 planting holes. In each hole, four seeds were placed, making a total of 40 seeds sown per experimental plot. The spacing between the plots was $90 \mathrm{~cm}$. Thus, the maximum theoretical density of plants in the experiments was 75,000 plants ha ${ }^{-1}$.

\section{Morphological evaluation}

Data for 58 morphological traits were taken from 10 randomly chosen plants from each plot. These characteristics were related to plant architecture (9), vegetative cycle (6), morphology of the leaf (5), morphology of the flower (12), morphology of the pod (14) and morphology of the seed (12) (Table 2). Traits related to pigmentation and coloration were observed between 08:00 and 09:00, using the colour chart from The Royal Horticultural Society (2001).

Data from the two vegetative cycles were compiled and the resulting mean values, standard deviation and variation indices were calculated for each parameter, independently and for all accessions. The Principal Components Analysis (PCA) was performed as described by Pinheiro de Carvalho et al. (2008), and used to summarize variability of the 50 
Table 2 Morphological traits considered in the study of Madeira common bean germplasm

\begin{tabular}{|c|c|}
\hline Abbreviations & Trait \\
\hline $\mathrm{D} 1 \mathrm{~F}$ & Days to first flower \\
\hline $\mathrm{NDF}$ & Days to flowering \\
\hline NDFF & Days until the end of flowering \\
\hline DF & Duration of flowering (days) \\
\hline NDM & Days to maturity \\
\hline ND1VS & Days until first dry pod \\
\hline $\mathrm{CH}$ & Hypocotyl length $(\mathrm{cm})$ \\
\hline $\mathrm{PH}$ & Hypocotyl pigmentation \\
\hline CCE & Emerging cotyledon colour \\
\hline $\mathrm{HC}$ & Plant type \\
\hline TCCF & Leaf colour of chlorophyll \\
\hline AP & Plant height $(\mathrm{cm})$ \\
\hline $\mathrm{PF}$ & Leaf persistence \\
\hline NNC & Node number at harvest \\
\hline DC & Stem diameter $(\mathrm{mm})$ \\
\hline $\mathrm{CF}$ & Leaflet length $(\mathrm{cm})$ \\
\hline LF & Leaflet width $(\mathrm{cm})$ \\
\hline FF & Leaf shape \\
\hline $\mathrm{CP}$ & Pedicel length (mm) \\
\hline NN1I & Node number until first inflorescence \\
\hline NGFI & Flower buds per inflorescence \\
\hline $\mathrm{NC}$ & Racemes per plant \\
\hline TB & Flower bud size \\
\hline $\mathrm{CDB}$ & Bracteole length (mm) \\
\hline LB & Bracteole width (mm) \\
\hline FB & Shape of bracteole \\
\hline $\mathrm{CB}$ & Colour of bracteole \\
\hline AA & Wing opening \\
\hline CAS & Colour of wings \\
\hline $\mathrm{CE}$ & Colour of standard \\
\hline $\mathrm{CV}$ & Pod length (mm) \\
\hline LV & Pod width (mm) \\
\hline AV & Pod height (mm) \\
\hline STV & Pod cross-section \\
\hline CUV & Pod curvature \\
\hline CVI & Immature pod colour \\
\hline CVM & Mature pod colour \\
\hline CVS & Dry pod colour \\
\hline PAV & Pod beak position \\
\hline OAV & Pod beak orientation \\
\hline CAV & Pod beak length (mm) \\
\hline PVP & Position of pods \\
\hline LOV & Locules per pod \\
\hline
\end{tabular}

Table 2 continued

\begin{tabular}{ll}
\hline Abbreviations & Trait \\
\hline FPV & Pod wall fibre \\
NVP & Pods per plant \\
NSV & Seeds per pod \\
PTS & Seed coat patterns \\
CME & Seed coat darker colour \\
CC & Seed coat lighter colour \\
NS & Apparent seed veining \\
CA & Hilar ring colour \\
BS & Brilliance of seed \\
CS & Length of seed $\left(\mathrm{mm}^{2}\right)$ \\
LS & Width of seed $(\mathrm{mm})$ \\
AS & Height of seed $\left(\mathrm{mm}^{2}\right)$ \\
FS & Seed shape \\
PS & Seed weight $\left(\mathrm{g} 100 \mathrm{seed}^{-1}\right)$ \\
VS & Seed volume $\left(\mathrm{cm}^{3} 100 \mathrm{seed}^{-1}\right)$ \\
\hline
\end{tabular}

accessions. Factor analysis of average values based on Eigenvalues was performed using SPSS version 16.0 for Windows. The Principal Coordinates Analysis (PCO) using the Gower general similarity coefficient was conducted to summarize variation and discriminate against the weight of the traits using MVSP version $3.13 \mathrm{~d}$ for Windows. Accession clusters were compared by one way ANOVA and discriminant analysis to assess their independence, to examine the relationships between groups and to identify the subset of features and variables that best distinguish populations and groups. $t$-Student tests were performed for each parameter to evaluate the existence of differences between the two vegetative cycles. One way ANOVA, discriminant analysis and t-Student tests were performed using SPSS version 16.0 for Windows.

\section{Results}

The results of the quantitative morphological traits for all populations, as well as for the dwarf and climbing bean groups separately, are presented in Table 3. Traits showed a wide range of variability, especially in plant height (AP), days until the end of flowering (NDFF), node number at harvest (NNC), pod length (CV), pods per plant (NPP), weight of 100 seeds (PS) and volume of 100 seeds (VS). 
Table 3 Morphological traits variability of the Madeiran beans

\begin{tabular}{|c|c|c|c|c|c|c|c|c|c|}
\hline \multirow[t]{2}{*}{ Traits } & \multicolumn{3}{|c|}{ Total } & \multicolumn{3}{|c|}{ Dwarf } & \multicolumn{3}{|c|}{ Climbing } \\
\hline & $N$ & Average \pm SD & Min-max & $N$ & Average \pm SD & Min-max & $N$ & Average $\pm \mathrm{SD}$ & Min-max \\
\hline $\mathrm{D} 1 \mathrm{~F}$ & 50 & $49.2 \pm 4.4$ & $42.0-61.0$ & 12 & $45.3 \pm 1.3$ & $43.0-48.0$ & 38 & $50.5 \pm 4.2$ & $42.0-61.0$ \\
\hline $\mathrm{NDF}$ & 50 & $52.6 \pm 4.6$ & $43.0-62.0$ & 12 & $47.8 \pm 1.4$ & $45.0-49.0$ & 38 & $54.1 \pm 4.2$ & $43.0-62.0$ \\
\hline NDFF & 50 & $77.5 \pm 7.9$ & $64.0-94.0$ & 12 & $66.3 \pm 2.5$ & $64.0-73.0$ & 38 & $81.0 \pm 5.4$ & $74.0-94.0$ \\
\hline DF & 50 & $24.9 \pm 5.5$ & $15.0-36.0$ & 12 & $18.4 \pm 2.5$ & $15.0-25.0$ & 38 & $26.9 \pm 4.5$ & $19.0-36.0$ \\
\hline NDM & 50 & $95.3 \pm 4.8$ & $89.0-108.0$ & 12 & $92.0 \pm 2.3$ & $89.0-95.0$ & 38 & $96.3 \pm 4.9$ & $90.0-108.0$ \\
\hline ND1VS & 50 & $94.8 \pm 4.6$ & $82.0-104.0$ & 12 & $91.3 \pm 3.9$ & $85.0-96.0$ & 38 & $95.9 \pm 4.3$ & $82.0-104.0$ \\
\hline $\mathrm{CH}$ & 50 & $4.2 \pm 1.2$ & $1.2-7.5$ & 12 & $3.3 \pm 1.1$ & $1.2-6.9$ & 38 & $4.5 \pm 1.1$ & $1.7-7.5$ \\
\hline AP & 50 & $192.2 \pm 108.7$ & $13.8-448.1$ & 12 & $25.7 \pm 5.5$ & $13.8-38.2$ & 38 & $244.8 \pm 63.2$ & $108.6-448.1$ \\
\hline NNC & 50 & $15.3 \pm 7.2$ & $3.0-37.0$ & 12 & $4.2 \pm 0.6$ & $3.0-5.0$ & 38 & $18.8 \pm 4.0$ & $10.0-37.0$ \\
\hline DC & 50 & $5.6 \pm 1.2$ & $2.9-9.9$ & 12 & $6.3 \pm 1.3$ & $4.0-9.9$ & 38 & $5.3 \pm 1.0$ & $2.9-8.4$ \\
\hline $\mathrm{CF}$ & 50 & $11.8 \pm 2.1$ & $6.2-18.4$ & 12 & $11.6 \pm 2.1$ & $7.2-18.4$ & 38 & $11.9 \pm 2.0$ & $6.2-17.3$ \\
\hline LF & 50 & $8.3 \pm 1.7$ & $4.5-15.1$ & 12 & $9.3 \pm 2.0$ & $5.2-15.1$ & 38 & $8.0 \pm 1.5$ & $4.5-12.0$ \\
\hline $\mathrm{CP}$ & 50 & $10.3 \pm 1.9$ & $5.2-16.3$ & 12 & $11.8 \pm 1.9$ & $8.3-16.3$ & 38 & $9.8 \pm 1.6$ & $5.2-15.9$ \\
\hline NN1I & 50 & $2.9 \pm 1.1$ & $1.0-7.0$ & 12 & $3.8 \pm 1.1$ & $2.0-7.0$ & 38 & $2.6 \pm 0.9$ & $1.0-5.0$ \\
\hline NGFI & 50 & $3.5 \pm 1.0$ & $2.0-7.0$ & 12 & $4.3 \pm 0.7$ & $3.0-6.0$ & 38 & $3.2 \pm 0.9$ & $2.0-7.0$ \\
\hline $\mathrm{NC}$ & 50 & $11.2 \pm 6.4$ & $3.0-42.0$ & 12 & $4.9 \pm 1.2$ & $3.0-8.0$ & 38 & $13.3 \pm 6.1$ & $3.0-42.0$ \\
\hline $\mathrm{CDB}$ & 50 & $7.0 \pm 1.0$ & $4.2-10.6$ & 12 & $6.7 \pm 1.0$ & $4.2-9.0$ & 38 & $7.1 \pm 1.0$ & $4.8-10.6$ \\
\hline LB & 50 & $4.7 \pm 1.0$ & $2.3-10.7$ & 12 & $4.2 \pm 0.7$ & $2.3-5.7$ & 38 & $4.8 \pm 1.0$ & $2.9-10.7$ \\
\hline $\mathrm{CV}$ & 50 & $160.0 \pm 37.8$ & $12.4-309.1$ & 12 & $142.7 \pm 21.4$ & $12.4-195.1$ & 38 & $165.5 \pm 40.1$ & $87.5-309.1$ \\
\hline LV & 50 & $11.4 \pm 1.1$ & $7.8-16.7$ & 12 & $11.4 \pm 1.0$ & $8.8-13.9$ & 38 & $11.4 \pm 1.2$ & $7.8-16.7$ \\
\hline AV & 50 & $15.9 \pm 2.5$ & $10.6-25.9$ & 12 & $14.4 \pm 1.3$ & $11.2-16.9$ & 38 & $16.4 \pm 2.6$ & $10.6-25.9$ \\
\hline CAV & 50 & $18.6 \pm 4.3$ & $6.4-33.8$ & 12 & $21.1 \pm 5.6$ & $6.4-33.8$ & 38 & $17.9 \pm 3.5$ & $7.6-31.9$ \\
\hline LOV & 50 & $5.9 \pm 1.6$ & $3.0-21.0$ & 12 & $5.2 \pm 0.8$ & $3.0-8.0$ & 38 & $6.1 \pm 1.7$ & $3.0-21.0$ \\
\hline NVP & 50 & $11.2 \pm 7.1$ & $2.0-56.0$ & 12 & $6.7 \pm 3.2$ & $2.0-22.0$ & 38 & $12.7 \pm 7.4$ & $3.0-56.0$ \\
\hline NSV & 50 & $5.6 \pm 1.2$ & $3.0-9.0$ & 12 & $5.0 \pm 0.9$ & $3.0-8.0$ & 38 & $5.9 \pm 1.3$ & $3.0-9.0$ \\
\hline $\mathrm{CS}$ & 50 & $14.4 \pm 2.1$ & $8.3-20.8$ & 12 & $13.8 \pm 1.9$ & $9.2-18.6$ & 38 & $14.6 \pm 2.2$ & $8.3-20.8$ \\
\hline LS & 50 & $6.9 \pm 1.2$ & $4.0-69.6$ & 12 & $6.5 \pm 0.8$ & $4.0-8.9$ & 38 & $7.0 \pm 1.2$ & $4.0-69.6$ \\
\hline AS & 50 & $8.9 \pm 1.0$ & $4.9-16.4$ & 12 & $8.3 \pm 0.7$ & $4.9-11.0$ & 38 & $9.1 \pm 1.1$ & $4.9-16.4$ \\
\hline PS & 50 & $60.2 \pm 12.7$ & $30.8-91.7$ & 12 & $52.1 \pm 7.0$ & $39.8-62.9$ & 38 & $62.8 \pm 13.1$ & $30.8-91.7$ \\
\hline VS & 50 & $49.0 \pm 11.4$ & $26.0-76.0$ & 12 & $43.0 \pm 8.8$ & $27.0-56.0$ & 38 & $50.9 \pm 11.5$ & $26.0-76.0$ \\
\hline
\end{tabular}

The table shows average values and standard deviation (SD), minimum (Min) and maximum (Max) for the 50 accessions (12 dwarf and 38 climbing)

The comparison of the evaluation for morphological traits in climbing and dwarf common bean populations (Table 3) revealed that the most significant differences were related to the NDF, NNC, AP, CV, NVP, NSV, PS, and VS parameters. When climbing bean samples were compared with dwarf beans there was a significant difference in plant height. Climbing beans also had a higher number of pods, of larger size, and heavier and larger seeds, which makes them more productive.
A Student $t$ test was performed to analyze morphological trait variation between the two vegetative growth cycles. Results indicate that variation was not significant except for two parameters (data not shown). These results allowed us to use an average for the two vegetative cycles in the following multivariate statistical analysis. The analysis divided the accessions along the first and second PCA axes, explaining $36.42 \%$ of the total variability (Fig. 1a). The PCO analysis using the Gower general similarity 

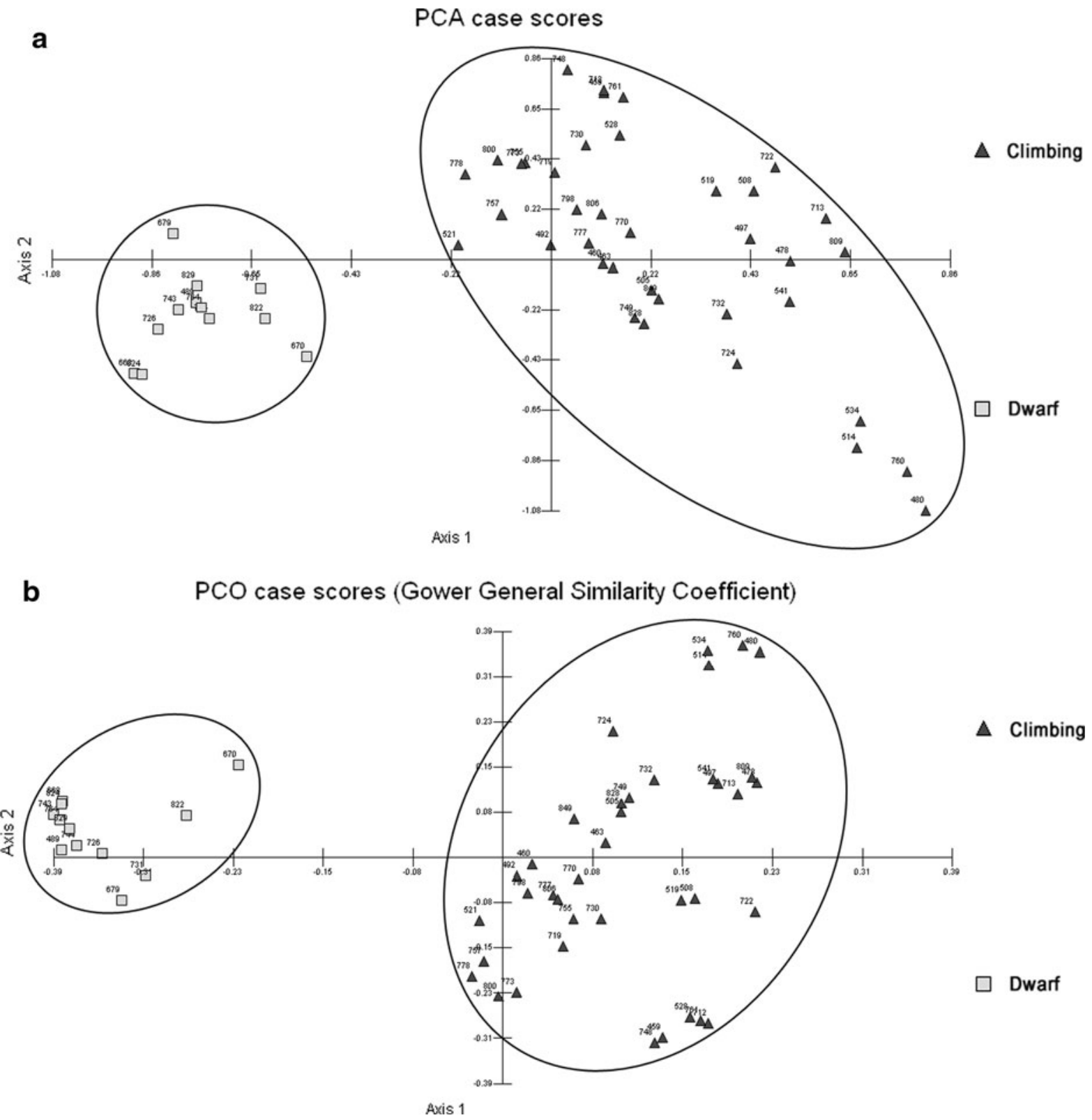

Fig. 1 a Principal Component Analysis of Madeira bean populations. The analysis allowed us to identify two groups of common beans (Dwarf and Climbing). b Principal Coordinates

coefficient to discriminate qualitative and quantitative traits showed an increase of the discontinuity of the accessions (Fig 1b). The separation along both PCO axes explains $26.85 \%$ of the observed variability.

This analysis permitted to pool bean accessions into two main groups according to the growth behaviour,
Analysis of Madeira bean populations, using the Gower similarity coefficient. The analysis allowed us to delimit two groups (Dwarf and Climbing)

the dwarf cluster, with 12 accessions, and the climbing one, including 38 accessions (Fig. 1). The discriminant analysis revealed that $100 \%$ of the accessions were properly classified. However, the spatial distribution of the accessions inside these groups allowed hypothesizing the existence of several different clusters inside the dwarf and climbing bean groups. To clarify further 

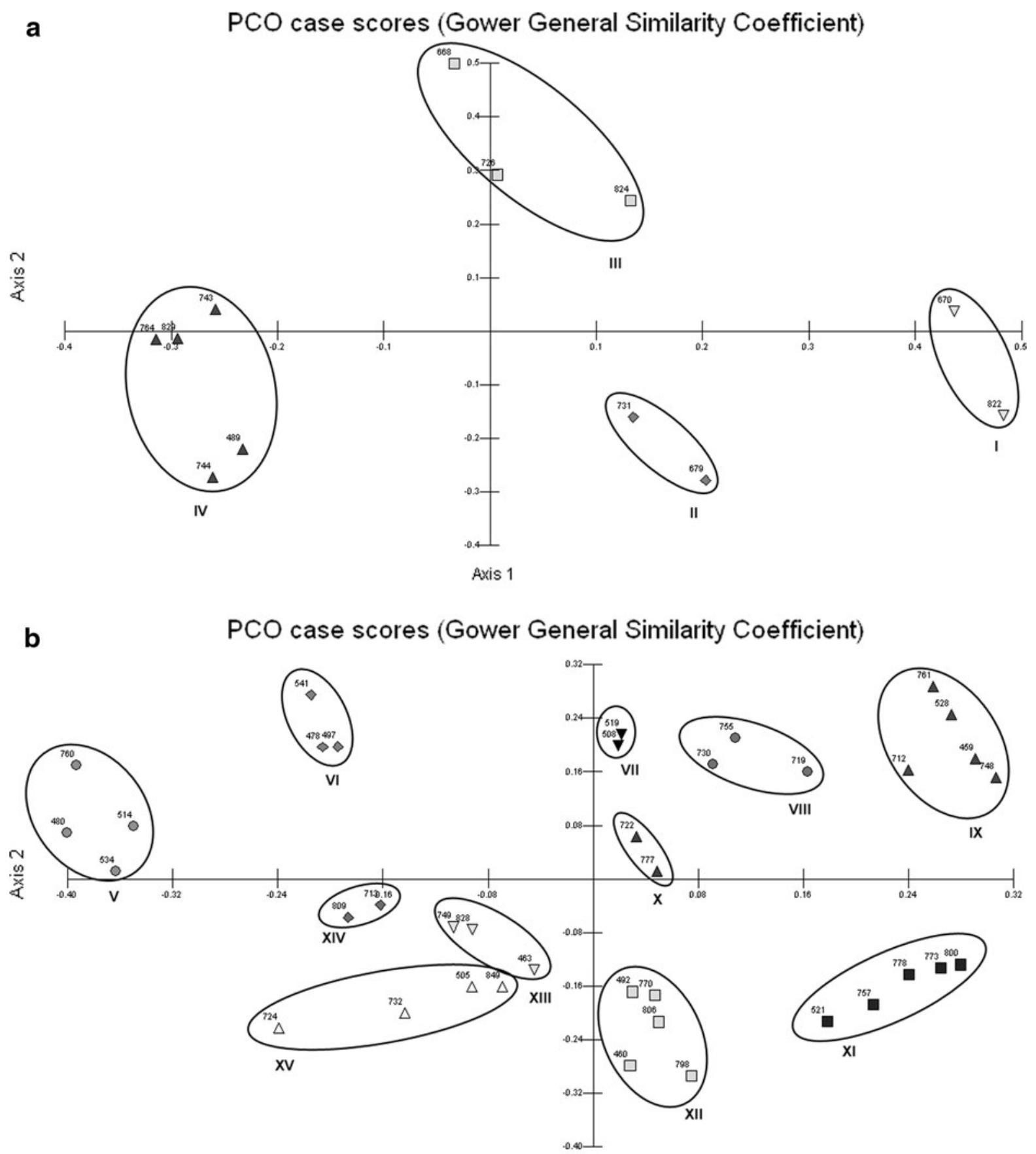

Axis 1

Fig. 2 a Principal Coordinates Analysis of Madeira dwarf beans populations, using the Gower similarity coefficient. The identified clusters are marked by a circle and marked from I to

the existence of sub-clusters, a separate and independent analysis was made for the dwarf and climbing beans groups.
IV. b Principal Coordinates Analysis of Madeira climbing bean populations, using the Gower similarity coefficient. The identified clusters are marked by a circle and marked V-XV

Figure 2a illustrates the PCO analysis performed on dwarf bean accessions, which grouped them into four clusters. In the PCO analysis using the 
Gower general similarity coefficient, both coordinates explained $41.69 \%$ of the total variability among the dwarf bean accessions. The spatial distribution of the accessions identified four clusters: I (ISOPs 670 and 822), II (ISOPs 679 and 731), III (ISOPs 668, 726 and 824) and IV (ISOPs 489, 743, 744, 764 and 829) (Fig 2a). This classification was subjected to a discriminant analysis, considering only quantitative traits, which revealed that $100 \%$ of the accessions have been properly classified. A group cross-validation confirmed that $83.3 \%$ of the cases were still correctly classified. The maximum degree of dissimilarity was determined using the generalized Mahalanobis distance, considering that the first two canonical variables accounted for $98.93 \%$ of the existing variability. The one way ANOVA procedure was used to confirm the existence of differences between the identified groups. Significantly different traits $(P \leq 0.05, \alpha \leq 0.05)$ were determined using the Tukey test. Mean values for these significant traits are summarised in Table 4. More detailed information about the traits that discriminate between individual groups can be found on Online Resource 1 .

The obtained results confirmed the existence of the dissimilarity between clusters and shown that they could be distinguished by several significant morphological and reproductive traits. The greatest differences were observed between clusters II and III, while the smallest difference was observed between clusters III and IV. The distance between each of the groups is suggested by the value of $\mathrm{F}$ obtained in the discriminant analysis. The lowest value of $F$ (303.25) confirmed that clusters III and IV are closer to each other, while clusters II and III were confirmed as the most distant, with the highest value of $F(3,723.03)$.

The same set of analysis was performed with the climbing beans. Figure $2 b$ illustrates the PCO analysis for climbing bean accessions, which grouped them into 11 clusters. In the PCO analysis using the Gower general similarity coefficient, the principal coordinate associated to axis 1 explained $15.76 \%$ of the total variation observed, while the one associated with axis 2 explained $11.74 \%$. The spatial distribution of the accessions allowed to identify eleven clusters: V (ISOPs 480, 514, 534, 760), VI (ISOPs 478, 497 and 541), VII (ISOPs 508 and 519), VIII (ISOPs 719, 730; 755), IX (ISOPs 459, 528, 712, 748 and 761), $X$ (ISOPs 722 e777), XI (ISOPs 521, 757, 773, 778 and 800), XII (ISOPs 460, 492, 770, 798 and 806), XIII (ISOPs 463, 749 and 828), XIV (ISOPs 713 and 809) and XV (ISOPs 505, 724, 732 and 849) (Fig 2b). This classification was submitted to discriminant analysis, using the same methodology as above, which revealed that $100 \%$ of the accessions were correctly classified, and correctly grouped in $84.20 \%$ of cases after crossvalidation. For this purpose, the maximum degree of dissimilarity was determined using the generalized Mahalanobis distance, considering that the first three canonical variables accounted for $96.73 \%$ of the existing variability. Results of ANOVA confirm the existence of differences between the identified groups. Significantly different traits $(P \leq 0.05, \alpha \leq 0.05)$ were determined using the Tukey test. Mean values for these significant traits are summarised in Tables 5 and 6. More detailed information about the traits that discriminate between individual groups can be found on Online Resources 2 and 3. These results show that

Table 4 Mean parameter values for clusters I-IV (dwarf beans)

\begin{tabular}{llrlrrrrr}
\hline Traits & $N$ & \multicolumn{1}{c}{ Cluster I } & $N$ & \multicolumn{1}{c}{ Cluster II } & $N$ & Cluster III & $N^{\circ}$ & Cluster IV \\
\hline D1F & 2 & $47.5 \pm 0.0$ & 2 & $45.5 \pm 0.0$ & 3 & $44.5 \pm 1.0$ & 5 & $44.7 \pm 0.3$ \\
NDM & 2 & $90.5 \pm 0.0$ & 2 & $90.3 \pm 1.1$ & 3 & $90.0 \pm 0.0$ & 5 & $94.6 \pm 0.4$ \\
DC & 2 & $5.2 \pm 0.6$ & 2 & $5.4 \pm 0.6$ & 3 & $5.6 \pm 0.2$ & 5 & $7.5 \pm 0.6$ \\
NGFI & 2 & $3.2 \pm 0.3$ & 2 & $3.2 \pm 0.2$ & 3 & $5.1 \pm 0.5$ & 5 & $3.6 \pm 0.1$ \\
CDB & 2 & $6.0 \pm 0.4$ & 2 & $5.9 \pm 0.1$ & 3 & $6.7 \pm 0.4$ & 5 & $7.4 \pm 0.5$ \\
LV & 2 & $10.5 \pm 0.2$ & 2 & $11.5 \pm 0.7$ & 3 & $10.6 \pm 0.6$ & 5 & $12.1 \pm 0.3$ \\
AV & 2 & $14.0 \pm 1.1$ & 2 & $14.4 \pm 1.0$ & 3 & $13.3 \pm 0.8$ & 5 & $15.3 \pm 0.3$ \\
LS & 2 & $6.3 \pm 0.6$ & 2 & $6.9 \pm 0.4$ & 3 & $5.7 \pm 0.4$ & 5 & $6.8 \pm 0.2$ \\
AS & 2 & $7.9 \pm 0.4$ & 2 & $8.8 \pm 0.2$ & 3 & $7.7 \pm 0.0$ & 5 & $8.7 \pm 0.2$ \\
\hline
\end{tabular}


Table 5 Mean parameter values for clusters V-IX (climbing beans)

\begin{tabular}{|c|c|c|c|c|c|c|c|c|c|c|}
\hline Traits & $N$ & Cluster V & $N$ & Cluster VI & $N$ & Cluster VII & $N$ & Cluster VIII & $N$ & Cluster IX \\
\hline D1F & 4 & $55.3 \pm 5.0$ & 3 & $55.5 \pm 1.7$ & 2 & $53.0 \pm 0.7$ & 3 & $48.8 \pm 2.9$ & 5 & $52.3 \pm 0.5$ \\
\hline NDFF & 4 & $83.1 \pm 5.6$ & 3 & $91.0 \pm 2.2$ & 2 & $86.5 \pm 0.0$ & 3 & $78.5 \pm 0.0$ & 5 & $78.0 \pm 0.0$ \\
\hline NDM & 4 & $98.3 \pm 3.6$ & 3 & $103.2 \pm 2.0$ & 2 & $101.8 \pm 1.1$ & 3 & $91.7 \pm 1.8$ & 5 & $94.8 \pm 2.7$ \\
\hline ND1VS & 4 & $96.0 \pm 4.4$ & 3 & $99.3 \pm 0.8$ & 2 & $97.5 \pm 5.0$ & 3 & $94.0 \pm 2.2$ & 5 & $98.2 \pm 2$ \\
\hline $\mathrm{CH}$ & 4 & $3.6 \pm 0.4$ & 3 & $4.3 \pm 0.9$ & 2 & $4.7 \pm 0.3$ & 3 & $3.8 \pm 0.5$ & 5 & $5.4 \pm 0.6$ \\
\hline $\mathrm{AP}$ & 4 & $298.0 \pm 13.2$ & 3 & $329.0 \pm 42.7$ & 2 & $319.1 \pm 16.8$ & 3 & $189.4 \pm 25.5$ & 5 & $194.4 \pm 6.5$ \\
\hline $\mathrm{NNC}$ & 4 & $19.8 \pm 1.8$ & 3 & $25.7 \pm 3.6$ & 2 & $23.5 \pm 0.4$ & 3 & $17.8 \pm 1.8$ & 5 & $16.5 \pm 0.5$ \\
\hline DC & 4 & $5.9 \pm 0.7$ & 3 & $5.3 \pm 0.4$ & 2 & $5.6 \pm 0.1$ & 3 & $4.5 \pm 0.7$ & 5 & $4.6 \pm 0.1$ \\
\hline $\mathrm{CF}$ & 4 & $11.7 \pm 0.8$ & 3 & $11.2 \pm 0.6$ & 2 & $11.3 \pm 0.4$ & 3 & $10.5 \pm 1.4$ & 5 & $10.1 \pm 0.6$ \\
\hline $\mathrm{LF}$ & 4 & $9.1 \pm 0.7$ & 3 & $7.3 \pm 0.5$ & 2 & $8.0 \pm 0.3$ & 3 & $6.7 \pm 0.8$ & 5 & $6.6 \pm 0.6$ \\
\hline $\mathrm{CP}$ & 4 & $8.2 \pm 0.9$ & 3 & $9.8 \pm 0.6$ & 2 & $10.0 \pm 0.3$ & 3 & $9.2 \pm 0.4$ & 5 & $8.9 \pm 1.0$ \\
\hline NN1I & 4 & $3.2 \pm 0.6$ & 3 & $4.4 \pm 1.1$ & 2 & $4.1 \pm 0.1$ & 3 & $3.1 \pm 1.2$ & 5 & $2.9 \pm 0.1$ \\
\hline NGFI & 4 & $3.5 \pm 1.0$ & 3 & $3.1 \pm 0.5$ & 2 & $3.7 \pm 0.1$ & 3 & $1.8 \pm 0.5$ & 5 & $2.5 \pm 0.1$ \\
\hline $\mathrm{NC}$ & 4 & $13.9 \pm 3.7$ & 3 & $19.7 \pm 6.0$ & 2 & $22.5 \pm 1.5$ & 3 & $12.7 \pm 5.8$ & 5 & $10.3 \pm 1.1$ \\
\hline $\mathrm{CDB}$ & 4 & $8.0 \pm 1.0$ & 3 & $6.7 \pm 0.7$ & 2 & $7.0 \pm 0.1$ & 3 & $6.5 \pm 0.3$ & 5 & $6.3 \pm 0.4$ \\
\hline $\mathrm{Lb}$ & 4 & $6.7 \pm 1.2$ & 3 & $3.8 \pm 0.3$ & 2 & $4.4 \pm 0.5$ & 3 & $4.6 \pm 0.3$ & 5 & $4.6 \pm 0.5$ \\
\hline $\mathrm{CV}$ & 4 & $239.7 \pm 31.4$ & 3 & $154.7 \pm 8.4$ & 2 & $132.0 \pm 15.2$ & 3 & $103.1 \pm 8.9$ & 5 & $134.1 \pm 8.9$ \\
\hline LV & 4 & $10.3 \pm 0.3$ & 3 & $10.4 \pm 0.6$ & 2 & $11.9 \pm 0.3$ & 3 & $11.9 \pm 0.8$ & 5 & $12.3 \pm 0.7$ \\
\hline CAV & 4 & $13.6 \pm 2.1$ & 3 & $15.5 \pm 2.0$ & 2 & $13.6 \pm 3.0$ & 3 & $16.9 \pm 1.7$ & 5 & $16.8 \pm 1.0$ \\
\hline LOV & 4 & $8.1 \pm 0.7$ & 3 & $6.5 \pm 0.4$ & 2 & $5.7 \pm 0.6$ & 3 & $5.4 \pm 0.3$ & 5 & $5.2 \pm 0.8$ \\
\hline NSV & 4 & $7.8 \pm 0.5$ & 3 & $6.3 \pm 0.2$ & 2 & $5.5 \pm 0.5$ & 3 & $5.2 \pm 0.1$ & 5 & $5.0 \pm 0.7$ \\
\hline $\mathrm{CS}$ & 4 & $14.0 \pm 0.8$ & 3 & $13.8 \pm 0.1$ & 2 & $11.7 \pm 0.7$ & 3 & $10.5 \pm 0.1$ & 5 & $13.8 \pm 1.1$ \\
\hline LS & 4 & $5.4 \pm 0.3$ & 3 & $6.9 \pm 0.2$ & 2 & $7.6 \pm 0.2$ & 3 & $7.8 \pm 0.3$ & 5 & $7.8 \pm 0.2$ \\
\hline AS & 4 & $7.5 \pm 0.6$ & 3 & $8.5 \pm 0.3$ & 2 & $9.1 \pm 0.1$ & 3 & $9.3 \pm 0.1$ & 5 & $10.2 \pm 0.7$ \\
\hline PS & 4 & $44.2 \pm 9.9$ & 3 & $54.6 \pm 3.8$ & 2 & $58.9 \pm 1.7$ & 3 & $52.7 \pm 2.2$ & 5 & $72.0 \pm 15.4$ \\
\hline VS & 4 & $35.1 \pm 7.6$ & 3 & $44.0 \pm 1.7$ & 2 & $46.3 \pm 1.8$ & 3 & $40.3 \pm 1.4$ & 5 & $59.4 \pm 12.7$ \\
\hline
\end{tabular}

the groups can be distinguished by several significant morphological and reproductive traits. This classification was confirmed by the values of $\mathrm{F}$ obtained by discriminant analysis. The greatest differences were observed between clusters XI and XIV (1,546.21). The smallest difference was observed between the clusters XII and XV (16.70).

\section{Discussion}

The accessions used in this study were representative of observed field diversity, local names and plant, pod and seed traits. We were able to observe a great variability in the majority of the studied traits among the 50 accessions. These results are consistent with Gepts and Bliss (1988), Rodiño et al. (2003) and
Rodiño et al. (2006), who studied the morphology of the Iberian Peninsula common bean germplasm. They concluded that the samples showed a high variability of the analysed morphological characters and this reflects the wide range of environments, in which crop resources evolved (Singh 1989; Singh et al. 1991b). This great variability has fuelled intensive discussions on the taxonomy and taxonomical structure of this species. Several authors have proposed classification systems to explain the intraspecific structure of common bean, but the classification used by Singh et al. (1991a) is the one that generates greater consensus giving a high taxonomic value to traits such as size, colour and seed shape in comparison to the vegetative characteristics of the plant.

Nevertheless, Smith and Smith (1989) emphasized the importance of the discriminating value of 
Table 6 Mean parameter values for clusters X-XV (climbing beans)

\begin{tabular}{|c|c|c|c|c|c|c|c|c|c|c|c|c|}
\hline Traits & $N$ & Cluster X & $N$ & Cluster XI & $N$ & Cluster XII & $N$ & Cluster XIII & $N$ & Cluster XIV & $N$ & Cluster XV \\
\hline $\mathrm{D} 1 \mathrm{~F}$ & 2 & $50.5 \pm 7.1$ & 5 & $45.7 \pm 1.9$ & 5 & $46.5 \pm 2.0$ & 3 & $51.3 \pm 3.3$ & 2 & $54.0 \pm 3.5$ & 4 & $48.1 \pm 1.1$ \\
\hline NDFF & 2 & $85.3 \pm 3.9$ & 5 & $74.5 \pm 0.0$ & 5 & $79.3 \pm 1.6$ & 3 & $77.8 \pm 1.2$ & 2 & $90.8 \pm 0.4$ & 4 & $80.0 \pm 2.3$ \\
\hline NDM & 2 & $101.0 \pm 7.8$ & 5 & $91.3 \pm 1.7$ & 5 & $95.1 \pm 0.7$ & 3 & $91.5 \pm 0.5$ & 2 & $105.3 \pm 0.4$ & 4 & $96.0 \pm 0.4$ \\
\hline ND1VS & 2 & $98.8 \pm 2.5$ & 5 & $91.1 \pm 4.0$ & 5 & $94.3 \pm 1.4$ & 3 & $95.0 \pm 0.5$ & 2 & $103.5 \pm 0.0$ & 4 & $94.9 \pm 3.5$ \\
\hline $\mathrm{CH}$ & 2 & $4.2 \pm 0.7$ & 5 & $5.3 \pm 0.6$ & 5 & $4.6 \pm 0.6$ & 3 & $4.6 \pm 0.7$ & 2 & $3.9 \pm 0.1$ & 4 & $4.3 \pm 0.6$ \\
\hline AP & 2 & $246.5 \pm 9.0$ & 5 & $223.7 \pm 30.3$ & 5 & $222.4 \pm 18.9$ & 3 & $195.2 \pm 32.7$ & 2 & $248.8 \pm 9.7$ & 4 & $284.6 \pm 55.0$ \\
\hline NNC & 2 & $22.1 \pm 3.6$ & 5 & $15.6 \pm 0.6$ & 5 & $18.2 \pm 0.8$ & 3 & $15.6 \pm 0.7$ & 2 & $18.4 \pm 0.1$ & 4 & $19.6 \pm 1.7$ \\
\hline DC & 2 & $1 \pm 0.2$ & 5 & $4.8 \pm 0.3$ & 5 & $6.3 \pm 0.6$ & 3 & $5.8 \pm 0.6$ & 2 & $5.3 \pm 0.1$ & 4 & $5.7 \pm 0.7$ \\
\hline $\mathrm{CF}$ & 2 & $10.9 \pm 1.4$ & 5 & $12.6 \pm 1.3$ & 5 & $13.2 \pm 1.2$ & 3 & $13.0 \pm 0.4$ & 2 & $12.3 \pm 0.8$ & 4 & $13.1 \pm 1.3$ \\
\hline LF & 2 & $7.8 \pm 1.4$ & 5 & $8.2 \pm 0.6$ & 5 & $8.8 \pm 1.0$ & 3 & $8.2 \pm 0.6$ & 2 & $8.1 \pm 0.9$ & 4 & $8.7 \pm 1.2$ \\
\hline $\mathrm{CP}$ & 2 & $9.5 \pm 0.4$ & 5 & $11.0 \pm 0.8$ & 5 & $10.4 \pm 1.7$ & 3 & $9.8 \pm 0.3$ & 2 & $8.1 \pm 0.5$ & 4 & $11.1 \pm 1.0$ \\
\hline NN1I & 2 & $3.9 \pm 1.2$ & 5 & $3.0 \pm 0.1$ & 5 & $2.7 \pm 0.2$ & 3 & $3.0 \pm 0.2$ & 2 & $4.1 \pm 0.3$ & 4 & $2.6 \pm 0.3$ \\
\hline NGFI & 2 & $2.7 \pm 0.1$ & 5 & $2.1 \pm 0.2$ & 5 & $2.2 \pm 0.4$ & 3 & $2.8 \pm 0.2$ & 2 & $2.6 \pm 0.1$ & 4 & $2.9 \pm 0.7$ \\
\hline $\mathrm{NC}$ & 2 & $15.2 \pm 2.4$ & 5 & $7.7 \pm 0.8$ & 5 & $12.7 \pm 1.8$ & 3 & $10.2 \pm 3.4$ & 2 & $15.5 \pm 0.3$ & 4 & $15.3 \pm 4.7$ \\
\hline CDB & 2 & $6.3 \pm 0.3$ & 5 & $7.1 \pm 0.9$ & 5 & $7.5 \pm 0.7$ & 3 & $7.4 \pm 0.7$ & 2 & $7.0 \pm 0.1$ & 4 & $7.5 \pm 0.6$ \\
\hline $\mathrm{Lb}$ & 2 & $4.6 \pm 0.1$ & 5 & $4.2 \pm 0.4$ & 5 & $4.8 \pm 0.5$ & 3 & $4.9 \pm 0.2$ & 2 & $5.2 \pm 0.2$ & 4 & $5.2 \pm 0.4$ \\
\hline $\mathrm{CV}$ & 2 & $158.3 \pm 22.7$ & 5 & $150.6=$ & 5 & $171.5 \pm 1$ & 3 & 175.8 & 2 & 19 & 4 & $=9.1$ \\
\hline LV & 2 & $11.1 \pm 0.0$ & 5 & $11.7 \pm 0.4$ & 5 & $11.3 \pm 0.6$ & 3 & $11.0 \pm 0.9$ & 2 & $12.6 \pm 1.0$ & 4 & $10.6 \pm 0.4$ \\
\hline CAV & 2 & $17.6 \pm 0.8$ & 5 & $19.2 \pm 1.2$ & 5 & $21.3 \pm 2.3$ & 3 & $20.1 \pm 2.5$ & 2 & $19.3 \pm 0.9$ & 4 & $19.7 \pm 0.8$ \\
\hline LOV & 2 & 5 & 5 & 3 & 5 & 8 & 3 & 6 & 2 & 1 & 4 & $=0.2$ \\
\hline NSV & 2 & $5.7 \pm 0.4$ & 5 & $5.0 \pm 0.2$ & 5 & $5.7 \pm 0.3$ & 3 & $6.2 \pm 0.6$ & 2 & $6.2 \pm 0.0$ & 4 & $6.4 \pm 0.2$ \\
\hline $\mathrm{CS}$ & 2 & $14.9 \pm 2.7$ & 5 & $14.8 \pm 0.7$ & 5 & $16.5 \pm 0.7$ & 3 & $16.8 \pm 0.2$ & 2 & $17.5 \pm 0.3$ & 4 & $15.1 \pm 0.3$ \\
\hline LS & 2 & $7.3 \pm 0.7$ & 5 & $7.2 \pm 0.6$ & 5 & $7.0 \pm 0.6$ & 3 & $6.9 \pm 0.4$ & 2 & $7.7 \pm 0.2$ & 4 & $6.3 \pm 0.2$ \\
\hline AS & 2 & $9.2 \pm 0.6$ & 5 & $9.7 \pm 0.6$ & 5 & $9.6 \pm 0.5$ & 3 & $8.7 \pm 0.5$ & 2 & $9.2 \pm 0.1$ & 4 & $8.5 \pm 0.1$ \\
\hline PS & 2 & $71.1 \pm 23.7$ & 5 & $63.1 \pm 5.3$ & 5 & $70.7 \pm 8.8$ & 3 & $64.6 \pm 10.2$ & 2 & $82.2 \pm 8.9$ & 4 & $60.0 \pm 5.3$ \\
\hline VS & 2 & $57.0 \pm 20.5$ & 5 & $52.3 \pm 3.1$ & 5 & $56.1 \pm 10.0$ & 3 & $55.7 \pm 6.5$ & 2 & $70.0 \pm 6.4$ & 4 & $47.3 \pm 4.1$ \\
\hline
\end{tabular}

morphological traits, which depends of the historical origin and the genetic pool of the studied accessions. According to Voysest (1983) large seeds (>40 g 100 seeds ${ }^{-1}$ ) correspond to bean of Andean origin. In our study, it is notorious the dominance of bean accessions with large seeds, indicating their possible Andean origin. This hypothesis is supported by the data of phaseolin pattern electrophoresis analysis of the Madeiran beans (da Silva et al. 2010). Our data are consistent with the results of the analysis of 88 germplasm accessions from northern Portugal performed by Rodiño et al. (2001b), who also observed the predominance of the Andean germplasm (seed size) over germplasm of Mesoamerican origin. The same result was observed by Igrejas et al. (2009). To ensure thorough morphological characterization, during the evaluation of the diversity of this crop on
Madeira, we analysed the results of field trials by multivariate statistics. The results of Student's $t$ test illustrate that, from all the characters studied, only the number of locules and seeds per pod shown significant differences $(P<0.05)$ between both vegetative periods. These results demonstrate that the samples had a great phenotypic stability and were well adapted to the agro-ecological conditions of Madeira. The successful adaptation to local edapho-climatic conditions explains why the bean is still used by local farmers and their preferences for old regional cultivars, which are differentiated by a specific number of morphological and agronomic traits. The verification of this stability allowed us to use average data from the 2 years for each parameter, for further statistical procedures (PCA, PCO, discriminant analysis and one-way Anova). Using the Principal Coordinates 
(PCO) analysis we were able to group the accessions according to their morphological variability (Fig. 1b). Two major morphological groups were distinguished among the common bean accessions by their growth behaviour, corresponding to the two varieties reported by Lowe (1862) to Madeira, namely Nana and Procerae varieties, which are homologous to the two subspecies defined by Maroto (1989), ssp. nanus (Kapri) Grad. (dwarf bean) and ssp. volubilis (Kapri) Grad (climbing beans).

The separated analysis of these groups using the PCA and PCO analysis detected 15 clusters (four dwarf beans and 11 climbing beans) (Fig. 2a and Fig. 2b), which according to the values of $F$ could be classified as racial groups. However, the Singh classification (Singh et al. 1991a) defines the existence of only three Andean races, which are the Chile, Nueva Granada and Peru races. Probably we are dealing with local varieties or landraces belonging to one or more of these Andean racial groups. Martins et al. (2006) proved that Portuguese white bean landraces were genetically very diverse, and we hypothesize that the same diversity occurs within Madeira landraces. This last hypothesis needs to be tested. Rodiño et al. (2001a) identified the existence of several landraces for the Iberian Peninsula common bean, e.a. groups of cultivars sharing the same morphological and genetic structure. Madeira varietal groups were described according to the identification of significant traits. Similar approach was used by Santalla et al. (1994), Rodiño (2001a, b), (2003) to define bean groups. The majority of these traits were associated with productivity or the characteristics of vegetative cycle, and significantly $(P \leq 0.05)$ differentiated the obtained clusters (Pinheiro de Carvalho et al. 2008). Thus, cluster III and IV were characterized by their early flowering precocity $(44.5 \pm 1.0$ and $44.7 \pm 0.3$ ), while cluster VI showed the longest vegetative cycle. The clusters with indeterminate growth habit, indeterminate arbustive and indeterminate climber, achieved physiological maturity later compared with the first four clusters having a determinate growth. The clusters $\mathrm{V}$ and $\mathrm{X}$ with indeterminate growth produced on average more pods per plant $(18.00 \pm 1.8$ and $17.3 \pm 7.2)$, and with the highest average number of seeds per pod $(5.7 \pm 0.4$ and $7.8 \pm 0.5)$. These observations are in agreement with studies conducted by García et al. (1997) who demonstrated that for the plants the increasing climbing ability determines the increase of the time needed for achieving physiological maturity, and that the plants with indeterminate growth are more productive than plants with determinate growth habit. According to Kinnear and Gray (2000), the $F$ values in a discriminant analyses with a magnitude higher than six values permit group validation, hence, we can conclude that the groups are spaced sufficiently to constitute distinct taxonomic units. The highest value of $\mathrm{F}$ observed for the dwarf bean clusters occurred between groups II and III, while the lowest recorded value of F was between groups III and IV, indicating that the first two groups are more spaced and the latter are those that share a greater number of morphological features. For the climbing beans clusters, the highest value of $\mathrm{F}$ was observed between groups XI and XIV. Groups VII and XV shared the largest number of features with the lowest value of $F$. A discriminant analysis exceeding proper classification of $80 \%$ of the cases is considered to be statistically reliable by Kinnear and Gray (2000). Thus, our results confirm that the groups defined by the PCO analysis were accurately classified, since $100 \%$ of the populations were correctly grouped including the dwarf and climbing beans.

On Madeira, the effect of artificial selection made by the local farmers and the adaptation of the varieties to different agro-climatic conditions could explain the balance achieved between the reproductive traits (productive) and the vegetative traits of the studied populations. This balance demonstrates that the combination of the two types of parameters allows a better characterization of the bean resources. This is consistent with the results reported by Santalla et al. (1994), Rodiño (2001a) and Rodiño et al. (2003), who concluded that the best descriptors should combine the production parameters with the vegetative parameters. Overall, for the traits used in the morphological evaluation of the common bean germplasm, the ones of particular importance are directly related with the growth cycle and reproduction. Regarding the Madeira beans, cultivars (ISOPs) 00521 and 00668 are characterized by an early flowering and pod maturation stage. These traits contribute to the reduction and incidence of pests and diseases (Rodiño et al. 2003). Yet, an early physiological maturity is negatively related to plant productivity (White and Singh 1991), therefore, a better assessment of these accessions for a posterior 
identification of their genotypes will be required. From an agronomical point of view, there are interesting cultivars with good quality of immature pods for fresh consumption, such as green beans (Rodiño et al. 2003). Madeiran ISOPs 00480, 00514, 00534 and 00760 , characterized by a greater pod length, may exhibit such potential. The ISOPs accessions 00480, 00519, 00534, 00724, 00760 and 00849 stand out by having a high grain yield per plant.

Scarcity of studies aiming to evaluate the Portuguese bean resources prevents the comparison of our results with a national reference. Rodiño et al. (2001b) and Igrejas et al. (2009) also present the Andean gene pool as dominant in Portugal. Our results seem to add to the hypothesis that Madeira bean germplasm was brought from mainland Portugal or followed the same introduction routes. There is evidence that Spanish bean germplasm does not share the same origin that the Portuguese one. Our research of the Madeiran germplasm suggests the existence of 15 groups of common beans, which could include landraces or hybrid varieties. Portuguese landraces were shown to be genetically diverse (Martins et al. 2006). It is probable that the same happens in Madeira. The high level of heterogeneity could be the result of different ecological adaptations, since the island mountainous terrain and steep valleys promoted the isolation of populations for centuries. Due to this isolation, genetic drift and low population size probably also contributed to the bean heterogeneity in Madeira. However, to confirm this hypothesis an array of detailed studies of the bean resources on Madeira, particularly involving further molecular and biochemical analyses, are warranted. The anticipated results would assist in trustworthy grouping of these accessions in the racial and landraces classification systems, proposed by Singh et al. (1991a) and by Rodiño et al. (2003), respectively. The evaluation and identification of local common bean landraces will be useful for the future development and implementation of research and breeding programmes. They could be a source of new genes, considering the fact that the Madeiran beans are well adapted to low-input sustainable farming systems and intercropping, frequently used on islands for bean production.

Acknowledgments The European Union has sponsored this work through the INTERREG IIIB programme, through the project Germobanco Agrícola da Macaronésia, 05/MAC/4.1/ C15. The Authors are grateful to the Madeiran farmers who assisted with collection of bean samples.

\section{References}

Araya CM (2003) Coevolución de interacciones hospedantepatógeno en fríjol común. Fitopatol Bras 28:221-228

Broughton WJ, Hernández G, Blair M, Beebe S, Gepts P, Vanderleyden J (2003) Beans (Phaseolus spp.) - model food legumes. Plant Soil 252:55-128

Cardador-Martínez A, Loarca-Piña G, Oomah BD (2002) Antioxidant activity in common beans (Phaseolus vulgaris L.). J Agric Food Chem 50:6975-6980

CIAT (1983) Etapas de desarrollo de la planta de fríjol común. Guía de estudio. CIAT (Centro Internacional de Agricultura Tropical), Cali

Da Silva EM, Correia ASA, Lopes NAA, Nóbrega HGM, Ganança JFT, Domingues AM, Khadem M, Slaski JJ, Pinheiro de Carvalho MÂA (2010) Phytogeographical origin of Madeiran common beans based on phaseolin patterns. Pesqui Agropecu Bras 45(8):863-871

Dos Santos TMM, Ganança JFT, Slaski JJ, Pinheiro de Carvalho MÂA (2009) Morphological characterization of wheat genetic resources from the island of Madeira, Portugal. Genet Resour Crop Evol 56:363-375

FAO (2009) Food and Agricultural Organization of the United Nations. http://www.faostat.fao.org/. Accessed in 30 June 2009

Freytag GF, Debouck DG (2002) Taxonomy, distribution and ecology of the genus Phaseolus (Leguminosae-Papilinoideae) in North America, Mexico and Central America. BRIT, Forth Worth

Ganança JFT, Abreu I, Sousa NF, Paz RF, Caldeira P, dos Santos TMM, Costa G, Slaski JJ, Pinheiro de Carvalho MÂA (2007) Soil conditions and evolution of aluminium resistance among cultivated and wild plant species on the island of Madeira. Plant Soil and Environ 53(6):239-246

García EH, Peña-Valdivia CB, Aguirre JRR (1997) Morphological and agronomic traits of a wild population and an improved cultivar of common bean (Phaseolus vulgaris L.). Ann Bot 79(2):207-213

Gepts P, Bliss FA (1988) Dissemination pathways of common bean (Phaseolus vulgaris, Fabaceae) deduced from phaseolin electrophoretic variability. II. Europe and Africa. Econ Bot 42:86-104

Graham PH, Ranalli P (1997) Common bean (Phaseolus vulgaris L.). Field Crops Res 53:131-146

Igrejas G, Carnide V, Pereira P, Mesquita F, Guedes-Pinto H (2009) Genetic diversity and phaseolin variation in Portuguese common bean landraces. Plant Genetic Resources $7(3): 230-236$

IPGRI (2001) Descritores para Phaseolus vulgaris. IPGRI International Plant Genetic Resources Institute, Rome

Kinnear PR, Gray CD (2000) SPSS for Windows made simple. Release 10. Psychology Press, Hove

Koenig R, Gepts P (1989) Allozyme diversity in wild Phaseolus vulgaris: further evidence for two major centres of genetic diversity. Theor Appl Genet 78:809-817 
Lowe RT (1862) A manual flora of Madeira and the adjacent islands of Porto Santo and the Dezertas, vol 1. John Van Voorst, London

Maroto JV (1989) Horticultura herbacea especial. Ediciones Mundi-Prensa, Madrid

Martins SR, Vences FJ, de Miera LES, Barroso MR, Carnide V (2006) RAPD analysis of genetic diversity among and within Portuguese landraces of common white bean (Phaseolus vulgaris L.). Sci Hortic 108:133-142

Mendes Ferrão JE (1992) A Aventura das Plantas e os Descobrimentos Portugueses. Instituto de Investigação Científica Tropical, Comissão Nacional para as Comemorações dos Descobrimentos Portugueses e Fundação Berardo, Lisboa (241 pp)

Pinheiro de Carvalho MÂA, Slaski JJ, dos Santos TMM, Ganança JFT, Abreu I, Taylor GJ, Clemente Vieira MR, Popova TN, Franco E (2003) Identification of aluminium resistant genotypes among Madeiran regional wheats. Comm Soil Sci Plant Anal 34(19-20):2967-2979

Pinheiro de Carvalho MÂA, Slaski JJ, Abreu I, Ganança FT, dos Santos TMM, Freitas L, Clemente Vieira MR, Nunes A, Antunes A, Taylor G (2004) Factors contributing to the development of aluminium tolerance in the Madeiran maize germplasm. J Plant Nutr Soil Sci 167:1-6

Pinheiro de Carvalho MÂA, Ganança JFT, Abreu I, Sousa NF, dos Santos TMM, Vieira Clemente RM, Motto M (2008) Evaluation of the maize (Zea mays L.) diversity on the Archipelago of Madeira. Genet Resour Crop Evol 55:221-233

Ranilla LG, Genovese MI, Lajolo FM (2007) Polyphenols and antioxidant capacity of seed coat and cotyledon from Brazilian and Peruvian bean cultivars (Phaseolus vulgaris L.). J Agric Food Chem 55:90-98

Rodiño, AP (2001a) Caracterización morfoagronómica y bioquímica de germoplasma de judía común (Phaseolus vulgaris L.) de España. Tesis de Doctorado. Universidad de Santiago de Compostela, España

Rodiño AP, Santalla M, Montero I, Casquero PA, De Ron AM (2001) Diversity of common bean (Phaseolus vulgaris L.) germplasm from Portugal. Genet Resour Crop Evol 48:409-417

Rodiño AP, Santalla M, De Ron AM, Singh SP (2003) A core collection of common bean from the Iberian Peninsula. Euphytica 131:165-175

Rodiño AP, Santalla M, González AM, De Ron AM, Singh SP (2006) Novel genetic variation in common bean from the Iberian Peninsula. Crop Sci 46:2540-2546

Santalla M, De Ron AM, Escribano MR (1994) Effect of intercropping bush bean populations with maize on agronomic traits and their implications for selection. Field Crops Res 36:185-189

Santalla M, De Ron AM, Voysest O (2001) European bean market classes. In: Amurrio M, Santalla M, De Ron AM (eds) Catalogue of bean genetic resources, PHASELIEU-FAIR-PL97-3463. Misión Biológica de Galicia (CSIC), Spain

Santalla M, Monteagudo AB, González AM, De Ron AM (2004) Agronomical and quality traits of runner bean germplasm and implications for breeding. Euphytica 135:205-215

Silva AF, Meneses CA (1984) Elucidário madeirense, vol 2. Secretaria Regional do Turismo e Cultura, DRAC, Funchal

Singh SP (1989) Patterns of variation in cultivated common bean (Phaseolus vulgaris, Fabaceae). Econ Bot 43:39-57

Singh SP, Gutiérrez JA, Molina A, Urrea C, Gepts P (1991a) Genetic diversity in cultivated common bean. II. Markerbased analysis of morphological and agronomic traits. Crop Sci 31:19-23

Singh SP, Gepts P, Debouck DG (1991b) Races of common bean (Phaseolus vulgaris, Fabaceae). Econ Bot 45:379-396

Singh SP, Nodari R, Gepts P (1991c) Genetic diversity in cultivated common beans. I. Allozymes. Crop Sci 31: 19-23

Smith JSC, Smith OS (1989) Description of distance between inbred lines of maize. The use of morphological traits as descriptors. Maydica 34:141-150

Strasburger E, Noll F, Schenk H, Schinder AFW (1994) Tratado de Botánica. $8^{\text {a }}$ Edición Española. Omega, Barcelona

The Royal Horticultural Society (2001) R.H.S. colour chart, 4th edn. The Royal Horticultural Society, London

Vieira P, Oliveira A (2007) Indicadores de Actividade Económica. Estatísticas da Agricultura e Pesca (Ano de 2006). Direcção Regional de Estatística, Funchal

Voysest O (1983) Variedades de fríjol en América Latina y su origin. CIAT, Cali

Voysest O, Dessert M (1991) Bean Cultivares: classes and commercial seed types. In: Van Schoonhoyen A, Voysest O (eds) Common beans; research for crop improvement. CIAT, Cali, pp 119-162

White JW, Singh SP (1991) Sources and inheritance of earliness in tropically adapted indeterminate common bean. Euphytica 55:15-19

Ying H, Zhiqiang C, Larry IH, Stuart BK (2006) Kaempferol in red and pinto bean seed (Phaseolus vulgaris L.). Coats inhibits iron bioavailability using an in vitro digestion/ human caco-2 cell model. J Agric Food Chem 54: 9254-9261 